\title{
Recovery stories - helpful or unhelpful? A randomised controlled trial
}

\author{
Lisa Dawson ${ }^{1 *}$, Paul Rhodes ${ }^{1}$, Barbara Mullan², Jane Miskovic ${ }^{3}$, Stephen Touyz ${ }^{1}$ \\ From 2014 ANZAED Conference: Driven Bodies Driven Brains \\ Fremantle, Australia. 22-23 August 2014
}

Low motivation to change and low self-efficacy have been associated with poorer outcome in anorexia nervosa (AN). There is evidence to suggest that sharing personal accounts of successful recovery with patients might improve motivation as well as helplessness and hopelessness associated with recovery, providing an important resource for sufferers. However, no research to date has explored the helpfulness or unhelpfulness of recovery narratives, despite many patients accessing such stories. The aim of the current study was to determine the efficacy of recovery narratives as a means of improving motivation and self-efficacy, using a randomised controlled trial design. The primary outcome variable was change in motivation as measured by intentions to recover from $\mathrm{AN}$ and stage of change. More than fifty individuals with AN and subclinical AN participated in this online study. Participants were randomised to either receive recovery stories or to a wait-list controlled group. After completing baseline measures, participants read five short stories about recovery from AN, and completed post-intervention measures two weeks later. Preliminary findings revealed that participants self-reported varying levels of usefulness. Full results regarding the effectiveness of the intervention as a means of improving motivation and self-efficacy are presented and clinical and research implications discussed.

This abstract was presented in the Learning from Consumers stream of the 2014 ANZAED Conference.

\section{Authors' details}

${ }^{1}$ The University of Sydney, Sydney, Australia. ${ }^{2}$ Curtin University, Perth, Australia. ${ }^{3}$ The Children's Hopsital, Westmead, Sydney, Australia.

Published: 24 November 2014

\footnotetext{
* Correspondence: lisa.dawson@sydney.edu.au

${ }^{1}$ The University of Sydney, Sydney, Australia

Full list of author information is available at the end of the article
}

doi:10.1186/2050-2974-2-S1-050

Cite this article as: Dawson et al: Recovery stories - helpful or unhelpful? A randomised controlled trial. Journal of Eating Disorders 2014 2(Suppl 1):O50.
Submit your next manuscript to BioMed Central and take full advantage of:

- Convenient online submission

- Thorough peer review

- No space constraints or color figure charges

- Immediate publication on acceptance

- Inclusion in PubMed, CAS, Scopus and Google Scholar

- Research which is freely available for redistribution

\section{() Biomed Central}

C Biomed Central

C 2014 Dawson et al; licensee BioMed Central Ltd. This is an Open Access article distributed under the terms of the Creative Commons Attribution License (http://creativecommons.org/licenses/by/4.0), which permits unrestricted use, distribution, and reproduction in any medium, provided the original work is properly cited. The Creative Commons Public Domain Dedication waiver (http:// creativecommons.org/publicdomain/zero/1.0/) applies to the data made available in this article, unless otherwise stated. 